\title{
THE EMERGENCE AND DEVELOPMENT OF TAXATION IN THE LEGAL TRADITION OF THE PEOPLES OF EASTERN EUROPE
}

\author{
Olha Sereda ${ }^{1}$
}

\begin{abstract}
The purpose of the article is to determine patterns of the creation of taxation given the centuries-long history of state-building of the peoples of Eastern Europe; to reveal the interaction of public and state elements as factors in creating a tax system. The use of dialectical, historical and legal, comparative methods allowed analysing standards, specifications and guidelines and solve a number of objectives: to find out the origin of taxes in the history of state creation; determine the laws of the origin and development of taxation in accordance with the nature of social relations; identify the factors that influenced the formation of taxation of the peoples of Eastern Europe. In the course of the study, it is found that taxation arises on the principles of self-government, social contract, and collective responsibility. Before the state creation, compulsory payments were collected from the population at the level of the communities and their associations in the form of "gifts" and "poliudie"; payment for the rituals; as well as tribute-farming. Objects of taxation were "dym" - a household with a house and a fire;"plough" a plough or a plot of land that could be cultivated with one plough. Generally recognized for peoples and states of the early Middle Ages was the payment of tribute-indemnity. Polans, Severians, Vyatichi paid tribute to the Khazars, and in the northwest of Rus - to the Varangians, the Drevlians - to the Kievan land. The process of forming the state (princely) tax system began by Prince Oleg from the abolition of tribute-farming in favour of other peoples and the establishment of an internal single tribute in favour of the Kievan land. Depending on the relations between the lands of Rus and the prince, this tribute acquired either the form of "gift" or farming. In 947, Princess Olga conducted a tax reform and used it for the affirmation of princely possessions. Places, norms, and sizes of tribute in favour of the princely treasury are determined. The results of the study will enable the tax institution to be recognized as a dynamic, historical phenomenon, formed on the basis of a social contract and a consolidating function.
\end{abstract}

Key words: tax history, tax, tax system, emergence of taxes, tribute, tribute relationships in Slavic tribes, tax system of Kievan Rus.

JEL Classification: B15, K10, N13, N43

\section{Introduction}

Taxes are a dynamic state-legal institute, a financial instrument of the state, which allows the state mechanism "to live" in the economic-legal space. This is an important link that directly or indirectly connects society with the state, thus involving it in the process of accumulation of financial resources for various strategic and social tasks. This relationship is supported by the state will and compulsion in accordance with the law. At such a "positivist" approach to understanding the nature of the tax, its social component is lost. At the moment, the institution is perceived solely as a state initiative, a general obligation and coercion. The social component is limited by the taxpayer and the addressee in the case of financing social needs (pensions, allowances, scholarships, reimbursements, etc.). Due to this, we observe a negative perception of the taxation system because of the lack of understanding and the idea of cooperation between the state and taxpayers. These are two opposing sides, where the latter took the position of the affected critics. Harmony and cooperation between them are possible under the condition of "rehabilitation" of legal awareness and formation of the tax system on the basis of the common good. It is in the field of tax relations that the principle of a social state should be implemented.

On this basis, a scientific study, the purpose of which is to reveal not only the state (normative) nature of taxes but also the public one, acquires a special relevance. Its research requires coverage of wide chronological boundaries, analysis and comparison of various historical cultures and formations. Such an approach with the help of dialectical, comparative, systemicstructural methods will allow solving a number of tasks:

\footnotetext{
Corresponding author:

${ }^{1}$ Yaroslav Mudryi National Law University, Ukraine.

E-mail: sereda_olha@ukr.net

ORCID: https://orcid.org/0000-0003-3018-0789
} 
to find out the origin of taxes in the history of statebuilding of the peoples of Eastern Europe; determine the laws of the origin and development of taxation in accordance with the nature of social relations; identify the factors that influenced the formation of taxation in the legal tradition of the peoples of Eastern Europe.

The genesis of the tax system in connection with the social processes of the ancient peoples and the Middle Ages is disclosed in the works of such researchers as N. I. Turgenev, V. A. Lebedev, E. Seligman, P. I. Tarasov, I. M. Diakonov, V. O. Kuri, S. M. Kashtanov, and others; changes in taxation during the bourgeois society were investigated by A. Smith, S. Gustav, O. HorbRomashkevych, I. Yanzhul, and others. It should be noted that the works of these authors have a doctrinal character, form the foundation for modern research in the field of tax law and its formation, in particular, by M. P. Kucheriavenko, M. M. Sheverdin, H. H. Osadcha, F. O. Yaroshenko, V. L. Pavlenko, and others.

\section{The main material}

The tradition of taxation of the peoples of Eastern Europe "was born" along with the state.

14 associations of East-Slavic tribes (Polans, Dulebs, Buzhans, Volhynians, Severians, Tivertsi, Uliches, etc.), which appeared in the history of the world as early as one thousand $\mathrm{AD}$, became the socio-political basis for the deployment of state-building processes. In the V-VIII centuries, their social organization was transformed into military-political unions in the form of tribal principalities: Polans and Severians with the centre in Kiev (the principality of Kiev); Ilmen Slavs, Krivichs, Chuds, Merya - near the city of Novgorod. Governance was carried out on the basis of a broad democracy, veche organization with the delegation of executive functions to an elected or "called" prince. The Byzantine historian Procopius of Caesarea described the political system of the Slavs as follows: "they are not governed by one person but have long been living in the rule of people and ... all things are always conducted jointly..." (Bojko, 1999).

This way of governance determined the procedure for satisfying the economic needs of the community and fulfilling its obligations on the principles of selfgovernment, the participation of the people in the decision of community affairs, collective bail, and responsibility. Common duties were the maintenance of the prince, the rituals; payment of military tributefarming. These forms of "financial" participation of the people became the first pre-state compulsory social contributions.

In cases of "calling" the prince, he was given a "gift" or a "tribute" in the sign of hospitality and goodwill of the community. "Gifting" of the prince was ritualsymbolic in nature. The population came to meet with gifts and bows, congratulating him during the poliudie - an annual autumn-winter visiting the lands of the principality. Therefore, the property received in this form was called "gifted poliudie".

Slavic principalities protected themselves whether they themselves were looking for booty from neighbouring peoples. In the area of relations between the winner and the conquered people, the common practice was the payment of tribute-indemnity. Tributeindemnity was paid periodically or one-time as farming for non-aggression in favour of the winner. This model was universally accepted for peoples and nations of the early Middle Ages.

Tribute-indemnity, as well as "gifted poliudie", was paid by "dym" - a household with a house and a fire. The object of taxation was also "plough" - a plough or a plot of land that could be cultivated with one plough. In turn, hunting tribes had the experience of paying tribute per head. Up to the $\mathrm{X}$ century, tribute was paid, as a rule, in natural form: squirrels, valuable fur, honey, grain, and others.

Slavic tribes had a rich experience in receiving and paying tribute in the form of indemnity. On the one hand, Procopius of Caesarea mentions Slavs and Antes who have plundered European lands with robbery and indemnities. The campaigns of the Slavs in 860, 907-911, and 941 to Byzantium (under the influence of the Khazar Khaganate) were slashing. According to the Rus-Byzantine treaties, the Greeks undertook to pay a tribute-indemnity, to free the merchants of Rus from paying customs duties, and took on the burden of their allowance for the time of stay in Byzantium.

On the other hand, the Primary Chronicle records that the Polans, the Severians, the Vyatichi paid tribute to the Khazars, and in the northwest of Rus - to the Varangians.

The Khazars in the VII-IX centuries created the state of the Khazar Khaganate in the territory of south-eastern Europe. They controlled the trade routes between East and West and pursued an active aggressive policy. One of the great victories was domination over the South Slavic centre. Slavs were obliged to pay tribute in favour of Khaganate: the Polans - a sword per hearth, the Severians and Vyatichi - "по белей веверице отъ аыма" (Litvina, 2002).

The Kievan Prince Askold became a tributary of the Khaganate and the Khagan military governor. Nestor the Chronicler described the Khazars' charging of the tribute from the Polans in the following lines. "Then the Khazars came upon them [the Polans] as they lived in the hills and forests, and demanded tribute from them. After consulting among themselves, the Polans paid as tribute one sword per hearth, which the Khazars bore to their prince and their elders, and said to them, 'Behold, we have found new tribute.' When asked whence it was derived, they replied, 'From the forest on the hills by the river Dnieper.' The elders inquired what tribute had been paid, whereupon the swords were exhibited. 
The Khazar elders then protested, 'Evil is this tribute, prince. We have won it with a one-edged weapon called a sabre, but the weapon of these men is sharp on both edges and is called a sword. These men shall impose tribute upon us and upon other lands.' All this has come to pass, for they spoke thus not of their own will, but by God's commandment." The Chronicler compared the dependence of the Polans from the Khazars with the Egyptian slavery of the Jews: "For the Egyptians perished at the hand of Moses, though the Jews were previously their slaves" (Dnipro, 1989).

In turn, the Varangians, according to the text of the Trinity list of the Novgorod Chronicle, were demanding “...Аань даяху Варягомъ от мужа по белки и веверици; а иже бяху у нихъ, то насилье деяху Словеномъ, Кривичемъ и Мерямъ и Чюди” (Puzanov, 2007). The burden and intensity of duties, according to historians, aroused a long-lasting economic crisis in the first quarter of the IX century.

However, in 862 , the local population managed to expel the Varangians "beyond the sea" and "began to rule by themselves." For better order and ending internal strife, the Slavs and the Finns made the decision to elect "собе князя, иже бы володелъ нами и судилъ по праву." According to Nestor the Chronicle, in 862, at the invitation of five tribes - two Slavic and three Finno-Ugric from the South Baltic, the Varangian dynasty comes to them: three brothers - Rurik, Sineus, and Turvor. However, their power was not absolute, the local elders retained their rule and influence. The princes divided the "Rus land" among themselves and began to reign and assigned cities to their followers. Among them were two boyars, Askold and Dir, who did not reach the Byzantine Empire "along the Dnieper", settled to reign in the land of the Polans (Tolochko, 1998).

The only successor after them was Oleg. The prince decided that Novgorod should pay the Varangians tribute to the amount of 300 grivnas a year for the preservation of peace and druzhina's service. This tribute to Varangians was received until the end of the reign of Yaroslav but already as a payment for military service. In 882, Oleg settled himself in Kiev and then the policy of consolidating the northern and southern Slavic tribes under his authority of the Kievan prince and the Kievan land began. This event has accelerated the development of state-building processes in Eastern Europe.

"Kievan Rus" formed as an early medieval state in the IX century in the process of political association of the East Slavic tribes. Its origin was not a single action, document or conquest. This is a unique way of multicultural interaction and consolidation of various pagan tribes of different levels of social organization (Slavs, Khazars, Varangians); Byzantine-Greek civilization. It conditioned the peculiarities of the formation of a state mechanism: the institutes of the head of state, the machinery, the court, and the taxation system. Their formation took place in the legal field of local Slavic and Scandinavian customs; rules of canon and Roman law (with the adoption of Christianity).

In the pursuit of supremacy and unanimous rule, Oleg demanded that the Slavs pay tribute to him according to the old custom "по всей Русстей земле." Any other forms of tribute to the conquerors abolished in favour of the prince. According to Laurentian Codex of the Chronicle, in 884, Oleg attacked the Severians, and conquered them, and imposed a light tribute upon them and forbade their further payment of tribute to the Khazars, on the ground that there was no reason for them to pay it as long as the Khazars were his enemies. The same mechanism was applied to the Radimichians. The Chronicle consolidated the negotiations' results, which stated that the tribute was paid to the Khazars, and at the same time, the demand of Oleg - "Do not pay the Khazars, but pay me ... And they paid Oleg a shilling apiece, the same amount that they had paid the Khazars." As a result, the Khazar Khanagate lost its Slavic tributaries. Thus, a new tribute was introduced on the one hand by force, and on the other - was a lighter alternative to previous tribute-indemnities.

Every land met the Kievan prince in different ways, and his goal was achieved either by force or by agreement: "Oleg began military operations against the Derevlians, and after conquering them he imposed upon them the tribute of a black marten-skin apiece. Thus Oleg established his authority over the Polans, the Derevlians, the Severians, and the Radimichians, but he waged war with the Ulichians and the Tivercians." Communities that "gifted" the prince or paid tribute as a farming did not lose their autonomy and lands. However, thus they recognized the military-political rule of the community of the Polyanians over other tribal associations. The refusal to pay tribute meant the dissolution of the political alliance with the prince and the transition to a state of war. So tribute did not become universal and did not turn into a state tax.

All forms of tribute out of the habit of the Slavswere paid during the poliudie to the prince, rarely - independently by the population in Kiev. The latter was called "povoz" or "podvoda". Gradually, the term "poliudie" combined various forms of payments from the population in favour of the prince: tribute, gifts, urok, bows, feeds, extraction, duties, and various fees.

With the increase of territories, the governors of the prince were delegated to places - "posadniks", elder "men" - druzhinniki. They were appointed from the inner circle of the prince. The time and place of the collection at first did not have a clear definition and created a space for conflict between the principality and the Kievan prince. A striking example of this was the Drevlian uprising against Igor in 945. The reason for the confrontation was an excessive "taxation" in response to the refusal of the Drevlians from their obligations after the death of Oleg. It is described in detail in the Primary Chronicle, which states: 
"Igor attacked the Drevlians in search of tribute. He sought to increase the previous tribute and collected it by violence from the people with the assistance of his followers." Returning to Kiev, he demanded more property, and he directed his druzhina to the Drevlians again. In response, the Drevlians consulted with their prince Mal and decided to protect from him as from the wolf that steals and kills the sheep. Disagreeing with the protest, Igor met with them in a battle near Iskorosten, where he was killed.

This conflict, during the days of Princess Olga, broke into a thin political struggle for liberation from the supremacy of the Kievan land on the one hand, and on the other - complete conquest of the Drevlians to Kiev and the transformation of the Ruthenia into the princely domain. She has captured Drevlian lands by force and cunning and "imposed upon them a heavy tribute, two parts of which went to Kiev, and the third to Olga in Vyshgorod; for Vyshgorod was Olga's city." Moreover, the princess standardized the order of collecting tribute throughout Rus: "Olga went to Novgorod, and along the [river] Msta she established trading-posts and collected tribute. She also collected imposts and tribute along the [river] Luga. Her hunting-grounds, boundary posts, towns, and trading-posts still exist throughout the whole region, while her sleighs stand in Pskov to this day. Her fowling preserves still remain on the Dnieper and the Desna, while her village of Olzhichi is in existence even now." (Dnipro, 1989).

Since 947, tribute and imposts began to be systematically charged at the appropriate time and of fixed size. Princess Olga defined "uroki" and "statutes". Uroki established a list of duties, which set the size and terms of payment of tribute. The size was determined for each tribe separately. Also, the "urok" was used in the sense of duty to be executed at a specified time and the exact size. A statute is a definition, an interpretation of the collection procedure. For the collection of taxes, "stanovyshcha" were defined administrative and financial points in the centres of rural communities - pogosty. These were the trading posts for the entire region, so it was here that the princely strongholds were located and princely men lived. They collected tribute, all duties, and also conduct a princely court on the principles of custom and law.

Consequently, the features of tax payments in the period of the establishment of the prince's authority and the consolidation of the Slavic lands under the authority of the Kievan prince were determined by the nature of his relations with the local princes, veche, and the community as a whole. The population paid tribute in the form of: 1) military tribute (Drevlians); 2 ) voluntary gift from the communities-allies (Polans); 3 ) state duty in the princely or patrimonial possession.

The introduction of a new system was firstly in the land of the Drevlians and then expanded from the southern part of Rus to the north.
Rules of the tax law of Kievan Rus became statutory determined in the code of common law - Russkaya Pravda. In the legislation of princes of XI-XII centuries, the term "оустави Аани" is used to define a tax. It marked a clear definition of the tribute size, time and place of its collection. A special attention should be paid to the structural part of the code - "Pokon virnyi". his document determined the amount of money and food that came to the prince's men when collecting the vira from the community.

With the advent of Christianity, there were taxes in favour of the clergy. These are various additional types of sales duties on domestic trade, such as duty on trade in fairs during temple holidays. Volodymyr the Great in 988 established the "tithe". It was intended for the construction of the Church of the Dormition of the Virgin (Church of the Tithes) in Kiev. Initially, it was temporary in the amount of one-tenth of the income of the population and eventually transformed into the lifetime right of the clergy.

Satisfaction of state needs was also carried out through a series of personal duties, non-monetary fees, and duties. The first included certain types of work for the maintenance of the princely estate and land (to set up a princely court, to feed horses, to mow the princely meadows, to cultivate his fields, to harvest wood, to provide chickens for princely falcons, go hunting, etc.). With the development of the princely estates, the money replaced the non-monetary form of taxation.

The international trade of the Slavs with the Byzantine Empire, the Khazar Khaganate, and the Arabian Caliphate exerted a considerable influence on the formation of tax relations of Kievan Rus. Due to the works of Arab writers, it can be concluded on the general rule for paying tithe on the borders of Rome, Khazaria from various types of Slavic goods. By the IX century, its own customs on the principle of collecting tithe was formed in Rus.

A separate category of taxes was customs duties and trade fees. Unlike the tribute, a collection of duties was carried out in monetary form. Among them, there are two groups: zastavni, which were levied before the start of trade for travel, and sales. Zastavni included poberezhni (from moored ships and boats); perevoz (by ferry or boat), mostovshchina (for passing through the bridge), kostki (for travel along the protected roads). The duties were levied on the person who carried the goods and the cargo. Internal duties and fees significantly impeded the development of trade, since their size and quantity were not regulated.

After the death of Yaroslav the Wise, centrifugal tendencies intensified in the Old Russian state. His sons failed to ensure effective management and lost control in internal strifes. Fragmentation between lands was facilitated by external factors - the Pechenegs' capture of Pereiaslavshchyna in 1068; and internal uprisings of the population, in particular, Kievans against Izyaslav. Feudal Councils (1097, 1100, 1101, and 1107) and 
wise reign of Vladimir Monomakh (1113-1125) only slowed the process of the collapse of Rus into separate independent principalities: Halych, Volhynia, Kiev, Murom, Pereyaslavl, Rostov-Suzdal, Chernihiv-Siversk, Polotsk-Minsk, Smolensk, Tmutarakan, Turov-Pinsk principalities, Novgorodian and Pskov lands. Already by the beginning of the XIII century, their number has reached 50. In each of the principalities, a model of taxation operated that was based on ancient customs.

\section{Conclusions}

1. The taxation in Kievan Rus arose and was carried out on the principles of self-government, social contract, and collective responsibility.

2. Before the state creation, compulsory payments were collected from the population at the level of the communities and their associations. The first "prestate taxes" were "gifts" and "poliudie" for the prince's allowance; payment for the rituals; as well as military tribute-farming. They were paid in natural form.
3. Generally recognized for peoples and states of the early Middle Ages was the payment of tributeindemnity. The Polans, the Severians, and the Vyatichi paid tribute to the Khazars, and in the northwest of Rus - to the Varangians, the Drevlians - to the Kievan land, at the time of the fragmentation and decline of Kievan Rus - to the Pechenegs and Tatar-Mongols.

4. Objects of taxation were "dym" - a household with a house and a fire; "plough" - a plough or a plot of land that could be cultivated with one plough.

5. The process of forming the state (princely) tax system began by Prince Oleg from the abolition of tribute-farming in favour of other peoples and the establishment of an internal single tribute in favour of the Kievan land. Depending on the relations between the lands of Rus and the prince, this tribute acquired either the form of "gift" or farming. In 947, Princess Olga conducted a tax reform and used it for the affirmation of princely possessions. Places, norms, and sizes of tribute in favour of the princely treasury were determined.

\section{References:}

Bojko, O. D. (2006). Istorija Ukrajiny [History of Ukraine]. Kiev: Akademvydav, 686 p. (in Ukrainian)

Dnipro (1989). Litopys Rusjkyj. Povistj mynulykh lit [The Ruschronicle. The tale of past years]. Kiev: Dnipro, 274 p. (in Ukrainian)

Litvina, A. F., Uspenskiy, F. B. (2002). Kievskaya i Moskovskaya Rus [Kiev and Moscow Rus]. Vol. 1, Moscow: Yazyki slavyanskoy kultury, 944 p. (in Russian)

Puzanov, V. V. (2007). Drevnerusskaya gosudarstvennost: genezis, etnokulturnaya sreda, ideologicheskie konstrukty [Old Russian statehood: genesis, ethnoculturus environment, ideological constructs]. Izhevsk: Udmurtskiy university, 624 p. (in Russian)

Tolochko, O. P., Tolochko, P. P. (1998). Kyjivsjka Rusj [Kievan Rus]. In V. Smolij (Ed.). Kiev : Aljternatyvy, 352 p. (in Ukrainian) 